\title{
Influences on Supervisors' Activities in Supporting Primary School of Bale Zone Sinana Woreda Cluster Resource Center (CRC)
}

\author{
By:- Yosef Hailu (MA, Lecturer) \\ MADAWALABU UNIVERSITY, P.o.box 247, Ethiopia
}

\begin{abstract} DOI: $10.7176 / \mathrm{JEP} / 10-28-03$

Publication date:October $31^{\text {st }} 2019$

\author{
Abbreviation \\ CRC- Cluster Resource Center \\ ETP-Education and Training Policy \\ MOE- Ministry of Education \\ REB-Regional Education Bureau
}

ZEO- Zone Education Office
\end{abstract}

This study was conducted on the influences of supervisor activities in supporting primary school of Sinana woreda CRC (Cluster Resource Center). The study basically focuses on the deficiencies of supervision in instructional processes in up grading teacher's competency to student learning ability. The main objective of the study were assess whether or not supervisors discharge role and responsibilities expected of them and to identify major factors that affect supervisors role in supporting educational supervision and propose solutions. The designs of the study were mainly a descriptive survey and method of sampling was purposive one. Five schools and 110 respondents were selected and participated on the study. For data collection questionnaires and structured interviews were used. Necessary data and information was collected, analyzed and interpreted. Results were tallied, organized presented in tables in which percentage were used. Finally on the major finding almost all teachers disclosed that supervisors conduct classroom observation once in a semester only for the completion of performance evaluation, supervisor endeavor regarding curriculum development tasks was rated as low by majority of teachers and average by supervisors themselves, both supervisors and teachers disclosed and showed the attempt of supervisors to hold pre-observation and post observation conference were below an average level. The major conclusion stresses classroom observation in the school lacks adherence to workable assistance and among the recommendation some ideas were suggested in order to solve the existing problems.

Key terms: Objective of Supervision, Curriculum Development, Instructional Improvement, Roles of Supervision

\section{Introduction}

\subsection{Background of the Study}

Education is a social phenomenon which contributes a lot of economic, social, cultural, and political development of a society. Through education human beings get behavioral changes by way of acquiring knowledge, skill, and attitude that enable them to become active and productive member of a society. Therefore, if we aspire to attain the desired result from education, we have to give an emphasis to strengthen educational management in general and education supervision in particular (Unkeje, 1992).

Educational supervision is an integral part of educational management that plays an important role in achieving the goal and objective of educational organizations by improving instructional activities. According to Ukeje (1992), to realize such an important role, supervisor should guide and coordinate the work of teachers and all connected with school works.

To improve instructional activities, supervisors have various role and responsibilities. In this regarded, various authorities have classified supervisory functions in various ways. Ujeje (1992) and wiles (1967) for instance, classified supervisory role into three broad functions. These are curriculum development, instructional improvement and continuing staff development. Lovell and wiles (1983), on the other hand grouped it in to curriculum development; in service education; psychological and technological support: goal development, implementation and evaluation. Signhal et.al (1996) divided the faction in to two broad functions namely maintenance faction involving evaluation and administrative faction: and development faction consisting of academic and development factions.

All the aforementioned ways of classification reveal the role of supervisors in the process of instruction improvement through academic and administrative faction in collaboration. To this end Tarrant and Newton (1992), pointed out that there is a need for those involved in supervision to integrate indicative, supporting and managerial role in to supervisory practice. 
Despite the fact supervision is an improvement oriented it is not always met with a happy handclasp by supervisees. This can attributed to many factors.

According to Gorton (1988) if supervisors don't display friendship, mutual trust, respect and warmth, teachers will not be satisfied and accepted the service. In line with this, Agarwal (1993) stated that work oriented supervisors who view their subordinates as people to get work done tend to cause low satisfaction with the supervisor and in turn create greater hatred towards supervision besides, the supervisor's inability to fill teacher's gap of inadequacies, to follow the necessary supervisory procedures causes to distort the practice. Furthermore, the incompatibility of supervisors' services provided with the roles teachers expert of supervisors in their academic deficiencies and other personal, and human relation inadequacies affect teacher's attitude negatively (Sergiovanni and Robert, 1993).

Historically, considerable change had been taken place in theory and practice during the past generation in the field of supervision.

Globally, in brief prior to 1900's supervision consisted largely of administrative supervision, beginning about the turn of century, it was maintained by specialists who showed teachers how to teach in the 1920's supervision began to be envisioned as a science (Scientific supervision) in which "laws" were discovered and let teachers apply; in 1930's and 1940's the emphasis lay upon democratic human relations in which great attentions were given to group processes and involvement of all teachers in problems mutual concern. Then, the emphasis was changed into democratic professional leadership which many countries apply currently (Otto and Sanders, 1962).

In Africa supervision and inspection were an innovation come with European colonial powers. Like any other aspects of influence the involvement and development of supervision were mainly of their reaction (Dull, 1981). For instance, Algeria has copied that of French's inspection practice; Nigeria and Zambia on the other hand tend to follow England inspection portion practice (Lyons \& Prichard in Grawue \& Carron, 1997). In many Africa countries external supervision happens suddenly for short period of time or inefficient, or both usually because of shortage of inspectors or because of communication difficulties (International Encyclopedia of Education, 1994).

With regard of Ethiopia, there has been constant shift from inspection to supervision and vice versa without any pedagogical justification. The latest change was made from inspection to supervision in 1994 as a consequence of the government change of 1991. The approach envisaged was democratic cooperative and professional supervision (Haileslassie,2002/3) in light of this approach the MOE, in its Educational supervision program manual of 1994, has pointed out that not only supervision at central, regional. or local levels but also in-school professionals, principals, vice principals, development heads, and senior teachers; have to take part in the supervisory activities. Their duties and responsibilities are to facilitate appropriate staff development, instructional improvement and curriculum development opportunities (MOE, 1994)

However, as it can be practically observed, the consideration given to such a crucial branch of education leadership appears to be disappointing or not as good as expended in Oromia regional state in general and Bale Zone Sinana woreda CRC in particular.

To this effect, it was this very discouraging trend of educational supervision that has initiated and paved way for the researcher to embark on studying this timely educational issue.

\subsection{Statement of the problem}

Education supervision is one part of a larger entity of the operation of educational system. It acts as are an important device for improving instruction and development teacher's imitative responsibility, creativity, internal commitment and motivation.

But, in Ethiopia in general and in Oromia in particular there are many factors that impede the performance as well as the effectiveness of supervisory activities. Among these some are: first, problem related to the techniques of supervision (lack of preparation for supervisory conference or meeting) second, problem to the inadequacy of supervisors (Be short of know how about management, pedagogical science and education and training policy to provide effective assistance of teachers) third, problem related to attitude (problems of supervisor's credibility to make supervisors, lack of commitment to provide honest services as effectively and efficiently as possible) (OEB, 2006).

Cognizant of this fact, the Ministry of Education of the federal Government of Ethiopia instituted supervision in place of inspection. In line with this, woreda level supervision department was organized and in built supervision which is a strategy to promote and sustain school supervision was introduced.

The inbuilt supervisors include principals, vice principals, department heads and senior teachers.

Although the policy frame work for the improvement of supervision service was superb. A comprehensive plan which takes into consideration all the inputs and the factors to produce optimal result in the form of woreda and school based supervision is illusive.

The existing practice of educational supervision, especially in Sinana woreda CRC reveals the same pattern. To site some evidence supervision was limited to routine inspection of administrative activities to check whether norms and standards are met, the provision of in service training programs to improve teachers competency is 
negligible, the trained woreda supervisors were posed to another position than supervisor, lack of know how about management, pedagogical science and education and training policy to provide effective assistances for teachers, lack of motivation and self confidence on the part of supervision, un skill way of using the technique of supervision. Service at a school level (WE, 2003-04)

Therefore, the aforementioned problems in primary school education supervision and the impact it might have on the education system have initiated the writer of the paper to undertake a study on the influences of supervisors' activities in supporting the primary school of Sinana woreda CRC. Thus, the main purpose/aim/of the study will be.

1. To indentify the focus of emphasis of current school supervisor in the process of supervision

2. To assess whether or not supervisors discharge roles and responsibilities expected of them.

3. To assess the techniques used by supervisors in the process of classroom observation.

4. To identify major factors that affect supervisors endeavor in supporting educational supervision and propose solution.

Hence, this study attempt to seek answers to the following basic questions, so that the study will be guided to the purpose.

1. How do supervisors perform their supervisory roles in educational supervision?

2. To what extent do supervisors perform their role in terms of staff development?

3. What are the problems that supervisors face in instructional improvement?

4. What are the problems that supervisors face in curriculum development?

5. To what extent do supervisors follow the produce of class room observation with regard to preobservation conference?

6. What factors do impede supervisors from performing their supervisory activities?

\section{The research design and methodology}

\subsection{Method of the study}

The study used descriptive survey method on the assumption that it helps to show the current state of factors that affect supervisor's endeavors in supporting primary school of Sinana woreda CRCs.

\subsection{Population of the study}

The populations of this study were 62 teachers 5 school principals, 4 vice principals, 2 cluster resource centers or CRC, 11 supervisors, and 20 department heads from the five primary schools.

\subsection{Sample and sampling techniques}

Sample population used for the study was $62(100 \%)$ teachers, $5(100 \%)$ school principals, $4(100 \%)$ vice principals, 2 cluster resource center(CRC), 11 (100\%) supervisors, with in the school 20 department heads and $5(100 \%)$ primary schools, were considered. Purposive sampling technique was used for all sample population, because they are experienced and more concerned with educational supervision service.

Table 1 Sample and sampling techniques

\begin{tabular}{|l|l|l|l|l|}
\hline \multirow{2}{*}{ Considered groups } & Total Population & \multicolumn{2}{|c|}{ sample } & Sampling \\
\cline { 2 - 5 } & & $\mathrm{N}$ & $\%$ & techniques \\
\hline Principals & 5 & 5 & 100 & purposive \\
\hline Vice principals & 4 & 4 & 100 & purposive \\
\hline Department heads & 20 & 20 & 100 & purposive \\
\hline Supervisors & 11 & 11 & 100 & Purposive \\
\hline Teachers & 62 & 62 & 100 & purposive \\
\hline Total & 102 & 102 & 100 & purposive \\
\hline
\end{tabular}

\subsection{Sources of data}

In this study both primary and secondary sources of data were used: secondary source were collected by direct access to education and record office of the schools to get information such as short and long term plan, supervisors' report, staff documents and supervisors' suggestion document.

Primary source were collected from school principals, vice principals, internal and external supervisors, department heads and teachers. The researcher used the secondary source of data to supplement the primary source and check the reliability of data.

\subsection{Data Collection instruments}

In order to obtain the desired information about the study, the researcher used two instruments questionnaires and structured interview (both close- ended and open - ended)- prepared in English and Afan Oromo (local language) versions. An interview was for cluster resource center or CRC supervisors, principals, vice principals and 
department heads because these bodies were more concerned about the issue. Separate questionnaire were prepared and distributed to all five selected school teachers and supervisors from within the schools.

\subsection{Method of data analysis}

The collected data were analyzed in a meaningful way. This was done in line with the response of the subject to whom the questionnaires and interviews administered. Statically methods were applied where necessary for analysis.

\section{Presentation, analysis and interpretation of data}

All the required data for the study was obtained through questionnaires and interview. Out of the total forty copies of questionnaires administrated to teachers and supervisors of sample schools, all (100 percent) were filled and returned. Moreover, structured interview was conducted with all CRC primary school supervision experts. The data gathered from the respondents were presented under each table using percentages and mean scores.

This section consists of two parts. Part one presents the characteristics of respondents, age, sex work experience and qualification. Part two discusses about analysis and interpretation of data. In line with this the problems that hinder the practice of supervision were discussed in detail.

\subsection{Characteristics of respondents}

Both supervision and teachers were asked to indicate their background information through questionnaires. Accordingly, their sex, age work experience, and qualifications were presented in table I.

\subsubsection{Sex and Age}

Table I Sex and Age of respondents

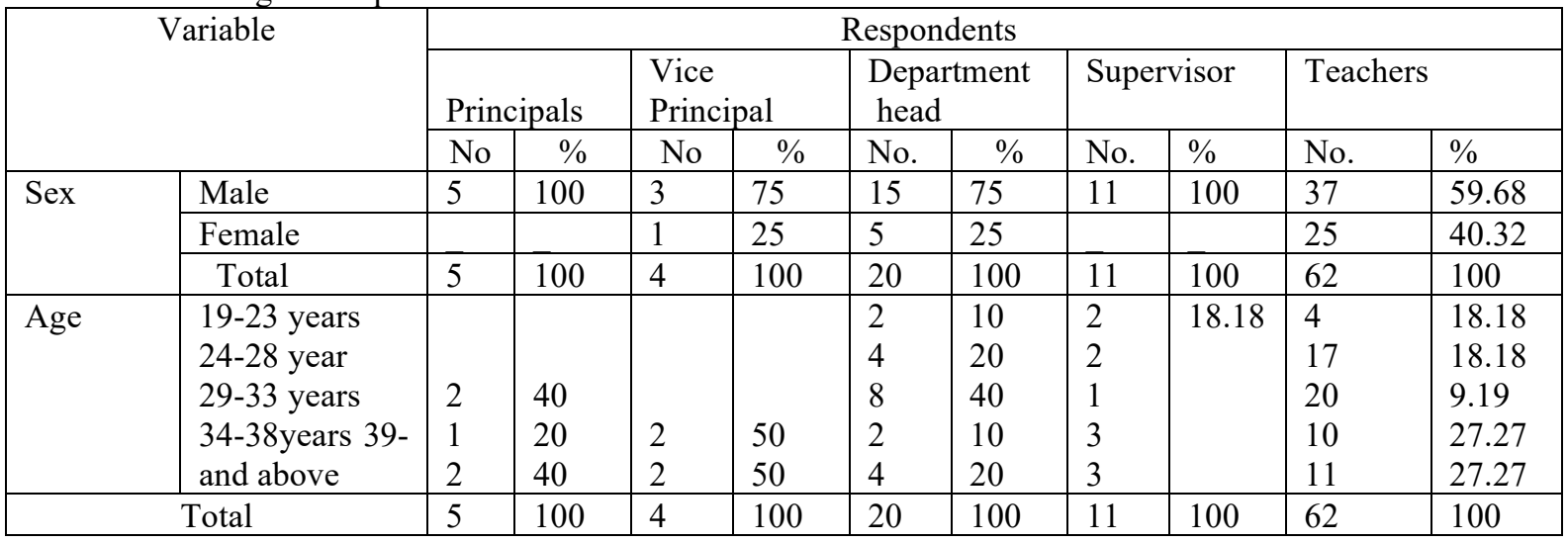

The table depicted the composition of respondents by sex and age. As can be seen, teachers, supervisors, department heads, vice principals and principals that account for $37(59.68 \%), 11(100 \%), 15(75 \%), 15(100 \%)$, $3(75 \%)$ and $5(100 \%)$ respectively were males where as teachers, department heads and vice principal account $25(40.32 / \%), 5(25 \%)$ and one $(25 \%)$ from female respectively.

The above table indicated that the female- male ration unbalanced in favor of males in teaching and there were no female supervisors and principals in the sample schools. This might be due to lack of interests on part of female teachers to be in appointed in supervisory positions, and less number of female teachers than male teachers. Regarding the age respondents, the majority of supervisors that is six (54.54 \%) fall in the age range of 34-39 years and above. From the analysis made so far, supervisors are a little bit more experienced than teachers. It is good that availability of more experienced and matured supervisors, principals and vice principals where schools are abound by young teacher, help the latter to adjust to the norms and culture and the community life, which in turn establish a healthy relationship with their work peers. 
3.1.2. Work experience and qualification

Table 2 work experience and qualification

\begin{tabular}{|c|c|c|c|c|c|c|c|c|c|c|c|}
\hline \multirow[t]{3}{*}{ Variable } & & \multicolumn{10}{|c|}{ Respondents } \\
\hline & & \multicolumn{2}{|c|}{ Principals } & \multicolumn{2}{|c|}{ Vice principals } & \multicolumn{2}{|c|}{ Department heads } & \multicolumn{2}{|c|}{ Supervisors } & \multicolumn{2}{|c|}{ Teachers } \\
\hline & & $\mathrm{N}$ & $\%$ & $\mathrm{~N}$ & $\%$ & $\mathrm{~N}$ & $\%$ & No & $\%$ & No & $\%$ \\
\hline Work & $1-5$ years & - & - & - & - & - & - & 1 & 9.09 & - & - \\
\hline \multirow[t]{4}{*}{ Experience } & 6-10years & 1 & 20 & - & - & - & - & 1 & 9.09 & - & - \\
\hline & 11-15years & 3 & 60 & 2 & 50 & 10 & 50 & 2 & 18.18 & 19 & 30.65 \\
\hline & 16-20years & 2 & 20 & 2 & 50 & 8 & 40 & 3 & 27.28 & 25 & 40.32 \\
\hline & 21 and above & - & - & - & - & 2 & 10 & 4 & 36.36 & 18 & 29.03 \\
\hline \multicolumn{2}{|c|}{ Total } & 5 & 100 & 4 & 100 & 20 & 100 & 11 & 100 & 62 & 100 \\
\hline \multirow[t]{3}{*}{ Qual. } & Certificate & - & - & - & - & - & - & 1 & 9.09 & 15 & 24.19 \\
\hline & Diploma & 4 & 80 & 4 & 100 & 20 & 100 & 9 & 81.82 & 33 & 53.23 \\
\hline & Degree & 1 & 20 & - & - & - & - & 1 & 9.09 & 14 & 22.58 \\
\hline \multicolumn{2}{|c|}{ Total } & 5 & 100 & 4 & 100 & 20 & 100 & 11 & 100 & 62 & 100 \\
\hline
\end{tabular}

As indicated in table II above, 7 (57.64\%) supervisors fall in the age range of 16-20 and 21 and above years respectively. On the other hand, $19(30.65 \%)$ and 25(40.32\%) teachers have served for 11-15 and 16-20 years respectively. Again on the other hand most and even all principals, vice principals and department heads fall in 11-15 and 16-20 years and above. From the above data meaningful assumption can be drawn in that supervisor's principals, vice principals and department heads are more experienced than teachers. This seems that supervisors are selected from among teachers' long years of service. The belief behind is that the more rich and varied the experience, the better new thing and activities they bring to the profession. Item II on table II reveals, one (9.09\%) and $15(24.19 \%)$ supervisors and teachers respectively are certificate graduates and $9(81.82 \%)$ supervisors and $33(53.23 \%)$ teachers are diploma holders. 4 (80\%), 4(100\%), 20(100\%) principals, vice principals and department heads were diploma holders, whereas 2(a principal and a supervisor) were degree holders. This shows that the educational level of supervisors is higher than that of teachers this might reveal that educational level is one of the consideration areas for the post of supervision.

\subsection{Objective of Supervision}

Table 3 Objective and practices supervision

\begin{tabular}{|c|c|c|c|c|c|}
\hline \multirow[t]{3}{*}{ No } & \multirow[t]{3}{*}{ Items } & \multicolumn{4}{|c|}{ Respondents } \\
\hline & & \multicolumn{2}{|c|}{ Supervisors $(\mathrm{N}=13)$} & \multicolumn{2}{|c|}{ Teachers $(n=27)$} \\
\hline & & $\mathrm{N}$ & $\%$ & $\mathrm{~N}$ & $\%$ \\
\hline 1 & $\begin{array}{l}\text { What do you think of on the main objectives of supervisor } \\
\text { A. Giving assistance for teachers } \\
\text { B. Completion of managerial activities }\end{array}$ & $\begin{array}{l}9 \\
2\end{array}$ & $\begin{array}{l}81.81 \\
18.19\end{array}$ & $\begin{array}{l}47 \\
15\end{array}$ & $\begin{array}{l}75.81 \\
24.19\end{array}$ \\
\hline \multicolumn{2}{|r|}{ Total } & 11 & 100 & 62 & 100 \\
\hline 2 & $\begin{array}{l}\text { Do supervisors perform supervisory activities in their } \\
\text { respective department according to its objectives? } \\
\text { A. Yes } \\
\text { B. No }\end{array}$ & $\begin{array}{l}10 \\
1\end{array}$ & $\begin{array}{l}90.9 \\
9.1\end{array}$ & $\begin{array}{l}4 \\
58\end{array}$ & $\begin{array}{l}7.94 \\
92.06\end{array}$ \\
\hline \multicolumn{2}{|r|}{ Total } & 11 & 100 & 62 & 100 \\
\hline
\end{tabular}

In item I of table III the respondents were asked to their opinion about the main objective of supervision. So, the obtained result reveals that $47(74 \%)$ teachers and 10(77\%) supervisor believed that the main objective of supervision is the provision of assistance for teachers. Some respondents, however, for instance, $15(24.19 \%)$ teachers replied that the intent of supervision is managerial activity. On the other hand $2(18.19 \%)$ supervisors responded that the intent of supervision is managerial activities.

The above information makes clear that most supervisors and teachers were well informed about the intent of supervision. However, there are some teachers and supervisors who understood the intent. This understanding may be emanated from sufficient orientation about the purpose of supervision and the existing reality of the practice.

In item 2 of the same table, nearly all teachers, that is $58(92.06 \%)$ asserted that supervisors did not implement their roles according to the objective. On the contrary, $10(90.9 \%)$ supervisors, however, justified that they perform their task according to its intent. The opinions of the two groups of respondents are contradicting, here, supervisors are diverting the objectives that supervision should (realize). The reasons may be due to lack of deep knowledge about supervisor or to use it as a fault finding mechanism. 


\subsection{Roles of Supervision}

The major roles that are performed by instructional supervisors are interactional improvement, curriculum development, and staff development through in - service education. Therefore, in an attempt to survey the view of teachers and supervisors on the extent of the accomplishment of the above roles, three point interval scales were used. According, the result obtained was presented below in frequency table.

\subsection{Instructional Improvement}

Table IV: Views on the endeavor of Supervisors to bring instructional improvement Table 4 Objective and practices supervision

\begin{tabular}{|c|c|c|c|c|c|}
\hline \multirow[t]{3}{*}{ No } & \multirow[t]{3}{*}{ Items } & \multicolumn{4}{|c|}{ Respondents } \\
\hline & & \multicolumn{2}{|c|}{ Supervisors $(\mathrm{N}=13)$} & \multicolumn{2}{|c|}{ Teachers $(n=27)$} \\
\hline & & $\mathrm{N}$ & $\%$ & $\mathrm{~N}$ & $\%$ \\
\hline \multirow[t]{2}{*}{1} & $\begin{array}{l}\text { Supervisors provision of assistance for teachers in } \\
\text { arranging and promoting situation conducive to } \\
\text { instructional improvement } \\
\text { 4.High } \\
\text { 3. Medium } \\
\text { 2. Low }\end{array}$ & $\begin{array}{l}2 \\
8 \\
1 \\
\end{array}$ & $\begin{array}{l}18.18 \\
72.73 \\
9.09\end{array}$ & $\begin{array}{l}11 \\
23 \\
28 \\
\end{array}$ & $\begin{array}{l}17.74 \\
37.10 \\
45.16 \\
\end{array}$ \\
\hline & Total & 11 & 100 & 62 & 100 \\
\hline \multirow[t]{2}{*}{2} & $\begin{array}{l}\text { Supervisor's organization of workshop meeting for } \\
\text { teacher to solve common instructional problems. } \\
\text { 4.High } \\
\text { 3. Medium } \\
\text { 2. Low }\end{array}$ & $\begin{array}{l}6 \\
4 \\
1 \\
\end{array}$ & $\begin{array}{l}54.55 \\
36.36 \\
9.09\end{array}$ & $\begin{array}{l}9 \\
19 \\
35 \\
\end{array}$ & $\begin{array}{l}12.9 \\
30.65 \\
56.45\end{array}$ \\
\hline & Total & 11 & 100 & 62 & 100 \\
\hline \multirow[t]{2}{*}{3} & $\begin{array}{l}\text { Supervisors help teachers in facilitating materials and } \\
\text { stimulate teacher to improve } \\
\text { 4.High } \\
\text { 3. Medium } \\
\text { 2. Low }\end{array}$ & $\begin{array}{l}7 \\
3 \\
1\end{array}$ & $\begin{array}{l}63.64 \\
27.27 \\
9.09\end{array}$ & $\begin{array}{l}21 \\
34 \\
7\end{array}$ & $\begin{array}{l}33.87 \\
54.84 \\
11.29\end{array}$ \\
\hline & Total & 11 & 100 & 62 & 100 \\
\hline \multirow[t]{2}{*}{4} & $\begin{array}{l}\text { Supervisors help teachers in facilitating materials and } \\
\text { stimulate teacher to improve } \\
\text { 4.High } \\
\text { 3. Medium } \\
\text { 2. Low }\end{array}$ & $\begin{array}{l}7 \\
3 \\
2 \\
\end{array}$ & $\begin{array}{l}63.64 \\
27.27 \\
9.09 \\
\end{array}$ & $\begin{array}{l}21 \\
34 \\
7 \\
\end{array}$ & $\begin{array}{l}33.87 \\
54.84 \\
11.29 \\
\end{array}$ \\
\hline & Total & 11 & 100 & 62 & 100 \\
\hline
\end{tabular}

In table IV, supervisors and teacher views on the extent of supervisors' endeavor to bring instructional improvement were organized.

Regarding the item majority that is $28(45.16 \%)$ revealed that the practice was low whereas, most supervisors i.e. $8(72.73 \%)$ rated their endeavor to be medium. The figures on the table showed that there is a difference of views on the extent of the effort above average while teachers evaluated the supervisors practice to be low.

In order to bring instructional improvement and increase students' achievement, supervisors are responsible in arranging and creating conducive environment. In light of this (Mbamba, 1992:106) revealed that the purpose of instructional supervision is to offer personal leadership advice to classroom teachers in the area related to the improvement of educational expertise of pupils. Holding the same idea, Adama and Dickay (1986:119) remarked that the supervisor is concerned with facilitating and stimulating teachers to improve instruction nevertheless, as to the data analyzed above, supervisors' effort in arranging and promoting conditions seems below expectations. This might emanate from lack of knowledge and competence in the field of supervision. In the same table item 2 , the two groups' responses on the arrangements of meetings for teachers to solve common instructional problems were organized. As rated by teachers the practice seems unsatisfactory. $35(56.45 \%)$ teachers witnessed that supervisors' effort to conduct meeting to solve instructional problems was low. On the contrary $6(54.55 \%)$ supervisor respondents believed that their arrangement of meetings for teachers to solve instructional problems was high.

The analysis made showed that there was a greater statistical difference between the views of both groups on the item under consideration.

From the theoretical point of view educational workshops and meeting may be organized so that teachers and supervisors cooperatively discuss various problems. In support of this idea, Mohanty (90:195) confirms that 
arranging meeting is a vital part of supervisor's role, without which a supervisor should not be complete. Through such meeting the supervisor solves the problems that teachers encounter and extend necessary guidance to them. However supervisors in the sample schools were found to be in efficient in this concern. Therefore, it seems that supervisors have been conducting workshop, conferences, and meeting which might not be regarded as relevant to teacher's problems in the school under treatment. Besides data from open -ended questions disclosed that there was lack of knowhow on the subject matter of supervision.

In item 3 of the same table, supervisors which account $63.64 \%$ responded that they highly helped teachers in facilitating instructional materials. Still, $27.27 \%$ of the same group replied that their practice on the item was at average level. But the majority of teacher asserted that supervisors' accomplishment level of the activity under consideration is below average. As one can understand there is an opposition between the views of supervisors and teachers. So, there might not be a working relation between teachers and supervisors.

In connection with this role, Mohanty (1990:27) indicated that a supervisor should aim at stimulating, coordinating and guiding the effort of teachers both individually and collectively for making their performance more effective. However, Supervisors of the sample school don't appear to shoulder their responsibility accordingly as the data in table III revealed.

\subsection{Curriculum development}

Table 5 The extent to which supervisors render supervisory support in curriculum development

\begin{tabular}{|c|c|c|c|c|c|}
\hline \multirow[t]{3}{*}{ No } & \multirow[t]{3}{*}{ Items } & \multicolumn{4}{|c|}{ Respondents } \\
\hline & & \multicolumn{2}{|c|}{ Supervisors $(\mathrm{N}=13$} & \multicolumn{2}{|c|}{ Teachers $(n=27$} \\
\hline & & $\mathrm{N}$ & $\%$ & $\mathrm{~N}$ & $\%$ \\
\hline \multirow[t]{2}{*}{1} & $\begin{array}{l}\text { Provision of recent and relevant } \\
\text { information for teachers in the } \\
\text { implementation and enrichment of } \\
\text { curriculum } \\
\text { 4. High } \\
\text { 3. Medium } \\
\text { 2. Low }\end{array}$ & $\begin{array}{l}4 \\
4 \\
3\end{array}$ & $\begin{array}{l}36 \\
36 \\
27\end{array}$ & $\begin{array}{l}15 \\
28 \\
19\end{array}$ & $\begin{array}{l}25.39 \\
44.44 \\
30.17\end{array}$ \\
\hline & Total & 11 & 100 & 62 & 100 \\
\hline 2 & $\begin{array}{l}\text { Working as a resource person in curriculum } \\
\text { 4. High } \\
\text { 3. Medium } \\
\text { 2. Low } \\
\end{array}$ & $\begin{array}{l}1 \\
7 \\
3 \\
\end{array}$ & $\begin{array}{l}15 \\
54 \\
31 \\
\end{array}$ & $\begin{array}{l}9 \\
6 \\
47 \\
\end{array}$ & $\begin{array}{l}14.29 \\
11.11 \\
34.60 \\
\end{array}$ \\
\hline & Total & 11 & 100 & 62 & 100 \\
\hline
\end{tabular}

In table $\mathrm{V}$ item 1, respondents were asked to forward their view on whether the school supervisors provide recent and relevant information to implement and enrich curriculum. Accordingly, 4 (36.36\%), 4 (36.36\%) and 3 $(27.27 \%)$ supervisors rated themselves as high, medium, and low respectively. Whereas the largest explained in the forgoing section analysis of supervisions seems to fall short of meeting the teachers' desire to update their curriculum knowledge. As indicated interviews, and discussions supervisors' lack of the skill, the training and the knowledge of supervision and budget deficit were the major reasons for the infectiveness of supervisors.

\subsection{Staff development through in - service education}

As authority in the field of educational supervision believe, teachers well as administrative force at school need an opportunity to grow professionally through an in - service education. Staff development through in service education, as major task of supervision, need to be accomplished by supervisory. Therefore, the table below shows the extent of supervisor's performance in activities under consideration. 
Table 6. The extent to which staff development through in service education is utilized

\begin{tabular}{|c|c|c|c|c|c|}
\hline \multirow[t]{3}{*}{ No } & \multirow[t]{3}{*}{ Items } & \multicolumn{4}{|c|}{ Respondents } \\
\hline & & \multicolumn{2}{|c|}{ Supervisors $(\mathrm{N}=13)$} & \multicolumn{2}{|c|}{ Teachers $(\mathrm{n}=27)$} \\
\hline & & $\mathrm{N}$ & $\%$ & $\mathrm{~N}$ & $\%$ \\
\hline 1 & $\begin{array}{l}\text { Extent of facilitation of professional development } \\
\text { programs as improving teacher performance in their } \\
\text { teaching create a better learning environment for student } \\
\text { 4. High } \\
\text { 3. Medium } \\
\text { 2. low }\end{array}$ & $\begin{array}{l}2 \\
3 \\
6\end{array}$ & $\begin{array}{l}18.18 \\
27.27 \\
54.55\end{array}$ & $\begin{array}{l}2 \\
6 \\
54\end{array}$ & $\begin{array}{l}3.23 \\
9.68 \\
87.09\end{array}$ \\
\hline & Total & 11 & 100 & 62 & 100 \\
\hline 2 & $\begin{array}{l}\text { Extent provision of latest information on teaching } \\
\text { theories and strategies for teachers } \\
\text { 4.High } \\
\text { 3.Medium } \\
\text { 2. low }\end{array}$ & $\begin{array}{l}2 \\
8 \\
21 \\
\end{array}$ & $\begin{array}{l}18.18 \\
72.73 \\
9.09 \\
\end{array}$ & $\begin{array}{l}2 \\
6 \\
54 \\
\end{array}$ & $\begin{array}{l}3.23 \\
9.68 \\
87.09 \\
\end{array}$ \\
\hline & Total & 11 & 100 & 62 & 100 \\
\hline
\end{tabular}

In the above frequency computation of item 1, the majority of teachers that is 54(87.09\%) replied that supervisors performed low. Similarly, thirty one percent $(54.55 \%)$ and $(27.27 \%)$ supervisors rated their endeavor to be low and medium respectively. Therefore, the result of the analysis showed that supervisors and teachers have similar ideal on the extent of performance of the under treatment.

Therefore, it is safe to say that, supervisors might not have either the understanding of the how of facilitating in- service training program or the budget and time to prepare the program.

With respect to item 2 of the same table, the highest score from the responses of teachers which accounts for $54(87.09 \%)$ stands for low. Still $9.68 \%$ same group rated the extent medium. On the other hand majority of supervisors that is $(72.73 \%)$ responded medium, whereas, $(18.18 \%)$ of supervisors indicated the extent high. From the analysis it can be observed that there is a divergent view of supervisors and teachers.

In light of the above roles supervisors authorities like, Lovell (1983:180) described that in- service education in a process through which professionals change and improve their teaching skills and general knowledge of the professionals change and improve their teaching skills and general knowledge of the procession in which they operate. Improving the quality, according to the author, is the immediate and long range objective of in- service education.

Hence, effective in-service training is defined from the very beginning as relevant to the task to teaching and is professionally rewarding and along with staff development through in service education.

Supervisors ought to support teachers by collecting and distributing latest information on the improvement of their profession. Nevertheless, the supervisory task of supervisors in facilitating staff development through in service education as seen in table $\mathrm{V}$ was below the expectation of teachers.

\subsection{Techniques of classroom supervisory procedure}

\subsubsection{Pre-Observation conference}

Table 7 Extent of the utilization of pre-observation conference

\begin{tabular}{|c|c|c|c|c|c|}
\hline \multirow[t]{3}{*}{ No } & \multirow[t]{3}{*}{ Items } & \multicolumn{4}{|c|}{ Respondents } \\
\hline & & \multicolumn{2}{|c|}{ Supervisors } & \multicolumn{2}{|c|}{ Teachers } \\
\hline & & $\mathrm{N}$ & $\%$ & $\mathrm{~N}$ & $\%$ \\
\hline $\begin{array}{l}1 \\
.\end{array}$ & $\begin{array}{l}\text { Supervisor's effort to hold pre observation } \\
\text { conference by making mutual agreements } \\
\text { on time, place and objectives of the } \\
\text { conference with teachers. } \\
\text { 4.High } \\
\text { 3. Medium } \\
\text { 2. low }\end{array}$ & $\begin{array}{l}1 \\
7 \\
3\end{array}$ & $\begin{array}{l}9.09 \\
63,64 \\
27.27\end{array}$ & $\begin{array}{l}10 \\
17 \\
35\end{array}$ & $\begin{array}{l}16.13 \\
27.42 \\
56.45\end{array}$ \\
\hline & Total & 11 & 100 & 62 & 100 \\
\hline
\end{tabular}

Pre-observation conference is one of the procedures of class room observation. Therefore, table VIII shows the extent of its utilization based on the views of both teachers and supervisors. Consequently, the greatest number that $56.45 \%$ teachers and $63.64 \%$ supervisors indicated the extent to be very low and medium respectively. Thus, teachers and supervisors have diverging views. Accordingly there was a little statistical difference.

The results obtained from the data analysis revealed that the pre-observation conference was underutilized. Supervisors visit teachers or schools accidentally without informing and agreeing with teachers. This might 
emanate from the previous experience of inspection program which was fault-finding. Similarly, data from all interview and open-ended question substantiated that there was no pre-observation conference except the knowledge that there is school supervision once a semester.

In connection with pre-observation conference, writers like Snyder in Harris (1985:52) stated that a preobservation conference is a contract accomplishment between supervisors and teachers. According to the writer, pre-observation conference is the procedures which necessitate clearance procedures for better and healthy classroom observation but these accounts seem to be less considered by supervisors as it was confirmed by the data in table VI and interview results.

\subsubsection{Class-room Observation Conference}

Table 8 Extent of the Utilization of class-room Observation

\begin{tabular}{|c|c|c|c|c|c|}
\hline \multirow[t]{3}{*}{ No } & \multirow[t]{3}{*}{ Activity } & \multicolumn{4}{|c|}{ Respondents } \\
\hline & & \multicolumn{2}{|c|}{ Supervisors $\mathrm{N}=13$} & \multicolumn{2}{|c|}{ Teacher $\mathrm{N}=27$} \\
\hline & & $\mathrm{N}$ & $\%$ & $\mathrm{~N}$ & $\%$ \\
\hline 1 & $\begin{array}{l}\text { Extent to take sufficient time for observing } \\
\text { the teachers teaching behavior during } \\
\text { classroom observation. } \\
\text { 4. High } \\
\text { 3. Medium } \\
\text { 2. Low }\end{array}$ & $\begin{array}{l}8 \\
2 \\
1 \\
\end{array}$ & $\begin{array}{l}72.73 \\
18.18 \\
9.09 \\
\end{array}$ & $\begin{array}{l}38 \\
14 \\
10 \\
\end{array}$ & $\begin{array}{l}61.29 \\
22.58 \\
16.13 \\
\end{array}$ \\
\hline & Total & 11 & 100 & 62 & 100 \\
\hline
\end{tabular}

As table IX revealed, $8(72.72 \%)$ rated the extent to be high similarly, most teachers that are $38 \quad(61.29 \%)$ replied high. Here, there is an affirmative relation of views of both respondents. Both indicated that the accomplishment of the task was above average. Besides, an interview result justified that there was classroom observation practice both for active and low performer teachers. But the frequency was once per semester due to lack of budget, lack of motivation and self confidence on the part of supervisors and lack of commitment provide hones services as effectively and efficiently as possible.

From the analysis made in table IX it is possible to conclude that supervisors take sufficient time whole period to record classroom interaction processes.

\subsubsection{Post Observation Conference}

Table 9 Degree o which post observation conference is utilized

\begin{tabular}{|c|c|c|c|c|c|}
\hline \multirow[t]{3}{*}{ No } & \multirow[t]{3}{*}{ Activity } & \multicolumn{4}{|c|}{ Respondents } \\
\hline & & \multicolumn{2}{|c|}{ Supervisors $\mathrm{N}=13$} & \multicolumn{2}{|c|}{ Teachers $\mathrm{N}=27$} \\
\hline & & $\mathrm{N}$ & $\%$ & $\mathrm{~N}$ & $\%$ \\
\hline 1 & $\begin{array}{l}\text { Extent to take sufficient time for } \\
\text { observing the teachers teaching } \\
\text { behavior during classroom } \\
\text { observation. } \\
\text { 4. High } \\
\text { 3. Medium } \\
\text { 2. Low }\end{array}$ & $\begin{array}{l}8 \\
2 \\
1 \\
\end{array}$ & $\begin{array}{l}72.73 \\
18.18 \\
9.09\end{array}$ & $\begin{array}{l}18 \\
17 \\
27 \\
\end{array}$ & $\begin{array}{l}29.03 \\
27.42 \\
43.55\end{array}$ \\
\hline \multicolumn{2}{|r|}{ Total } & 11 & 100 & 62 & 100 \\
\hline 2 & $\begin{array}{l}\text { Extent to which supervisors provide } \\
\text { the summary of the analysis to the } \\
\text { observation result in written for } \\
\text { 4. High } \\
\text { 3. Medium } \\
\text { 2. Low }\end{array}$ & $\begin{array}{l}1 \\
2 \\
8 \\
\end{array}$ & $\begin{array}{l}9.09 \\
18.18 \\
72.73 \\
\end{array}$ & $\begin{array}{l}6 \\
9 \\
47 \\
\end{array}$ & $\begin{array}{l}9.68 \\
14.52 \\
75.8 \\
\end{array}$ \\
\hline & Total & 11 & 100 & 62 & \\
\hline
\end{tabular}

In table $\mathrm{X}$ item 1 , the extent of conducting post-observation conference was rated. The result showed that, the greatest number of supervisors, that is $8(72.73 \%)$ and $2(18.18 \%)$ rated their performance to be high and average respectively. Whereas $18(29.03 \%), 17(27.42 \%)$ and $27(43.55 \%)$ teachers respondents reported the extent to be high, medium and low respectively. In the same table item $28(72.73 \%$ supervisors and $47(75.8 \%)$ teachers responded that supervisors' accomplishment of the activity under treatment was very low.

An effort was an affirmative relation with supervisors' views. The implication is that supervisors do not give written summary of observation comments for teachers. This seems that supervisors have no intention to use the observation comments, mostly the weakness acts, for future performance appraisal, or they keep the points that 
need improvement secret and use for criticism.

Concerning post-observation activities, post observation conference behavior includes the analysis of the data collected during observation of instruction, the evaluation of teaching and learning behavior, the process of providing feedback teachers and the like. But as it was revealed by the analysis the theory and the actual practice are not in agreement in the sample schools of Sinana woreda under study.

\subsection{Summarize results of open-ended interview question}

Showed: the major problems that hinder supervisory practice were:

1. Lack of supervisory knowledge and skill

2. Heavy work load

3. Lack of clear supervision guideline, responsibility, principles

4. Lack of training in the field

5. Shortage of budget

\section{Summary, conclusion and recommendation}

This chapter deals with the summary of the major findings and the conclusions reached and the recommendations forwarded on the basic of the finding.

\subsection{Summary}

This research was conducted in the primary schools of CRC in Sinana woreda in Bale Zone Oromia regional state. Its purpose was to survey the factors that affect supervisors' endeavors in supporting of instructional supervision of the schools understudy. The subject of the study were five schools, which were randomly selected from the woreda and all teachers and supervisors (school based) of the sample schools were included in the study.

Data were obtained through questionnaires from sampled schools respondents and through interview from CRC primary school supervision experts. Percentages were used for the analysis of the obtained data. Hence summary of the major findings are:

1. The sampled schools supervisors and principals are all males but there are some $25 \%$ female vice principals, $25 \%$ female department heads and $25(40.32 \%)$ female teachers were engaged in teaching in the sample schools.

2. The majority of supervisor respondents fall in the age range of 34-38 and above. Regarding work experience, more than half of them have served for greater or equal to sixteen years.

3. $9(81.82 \%)$ supervisors are diploma holder whereas $15(24.19 \%)$ teachers are certificate graduates. $4(80 \%)$, $4(100 \%)$ and $20(100 \%)$ principals are certificate graduates. $4(80 \%), 4(100 \%)$ and $20(100 \%)$ principals, Vice principals and department heads were diploma holders, where as $20 \%, 7.7 \%$ and $19.05 \%$ principals, teachers, vice principals were degree holders respectively.

4. The vast majority of both groups of respondents that is $10(77 \%)$ supervisors and $47(74.6 \%)$ teachers confirmed that the main intent of instructional supervision is giving assistance for teachers. Nevertheless, $92.6 \%$ of the teachers pointed out that the current actual practice was not in accordance with its intent.

5. Almost all teachers conduct classroom observation once a semester only for the completion of performance evaluation.

6. As indicated $28(44.44 \%)$ vast majority of teachers evaluated the extent of performance of instructional improvement activities were low, whereas supervisors didn't agree with this view.

7. Supervisors' endeavor regarding curriculum development tasks was rated as low in item 2 by majority of teachers, and average by supervisors themselves.

8. It was confirmed by most respondents from both groups that the extent of facilitating staff development programs such as in-service trainings were below average.

9. As it is disclosed in the analysis by both supervisors and teachers, the attempt of supervisors to hold preobservation conference is low.

10. The findings showed that supervisors hold post observation conference below an average level.

11. The majority of respondents replied that supervisor's effort to provide the summarized written feedback for teachers after observation was very low.

12. As the summarize results of open-ended questions and interview showed, the major problems that hinder supervisory practice are lack of supervisory knowledge and skill, heavy work load, lack of clear supervision guide lines and structure, responsibility, principles, lack of training in the field, shortage of budget.

\subsection{Conclusion}

Based on the findings indicated above, the following conclusions were drawn:

1. As the findings revealed there was no female supervisor in the subject schools. This seems that the assignment of teachers in supervisory responsibilities in the primary schools of Sinana woreda CRC did not consider the 
participation of females.

2. It has been found out that the assignment of teachers in supervisory positions consider work experience and educational level. Therefore, it is possible to say that in primary schools of Sinana woreda CRC under the study were well informed that experience and qualification are required for the tasks of supervision, principals, vice principals and department heads.

3. The findings of the study revealed that teachers and supervisors are aware of the main intent of supervision. Yet, teacher's response pointed out that the actual practices of supervisors are not in line with the desired objective of the service. The focus is on completion of performance appraisal than helping teachers. Hence, we can conclude that supervisors of the schools under study did not pay attention to the real objective of instructional supervision to performance evaluation.

4. Instructional supervisors are mainly charged with core tasks like curriculum development, instructional improvement and staff processional development.

5. The findings of the study however, disclosed that the endeavors of supervisors to shoulder such responsibilities are significant. Hence, it is possible to conclude that the current in School Instructional supervisors of the schools under study are incompetent and deficient to handle their role expectations.

6. Classroom observation is one of the foci of attention of instructional supervisor in the process of improving instruction. Nevertheless, the study has found out that:

a. Supervisors hold classroom observation once a semester per teacher for the purpose of completing performance appraisal.

b. Supervisors do not hold pre-observation conference with teachers or underutilized.

c. Supervisors do not provide a summary of written feedback after observation

Owing to these, we can conclude that the classroom observation process of the supervisors of the schools under study lacks adherence to workable principles both in and outside class room. Therefore, classroom observations of the schools under study lack competence in providing a desirable assistance.

\subsection{Recommendations}

1. To provide leadership for instructional improvement and to create conductive learning environment, instructional supervisors are expected to undertake the different tasks to supervision like curriculum development, instructional improvement and stuff professional development. However, it has been found that supervisors of the schools understudy are different and in competent to handle their roles. Hence, is advisable to start with introducing them with supervisory roles and supervisory skills required of them. To this effect, the WEO together with schools should plan and organize short-term in service training programs to acquaint them with the skill and the knowledge of instructional supervision.

2. It has been found out that the procedural techniques of class room observation were violated. Supervisors carry out observation process unplanned without mutual consensus of teachers. They accidentally enter classroom. No written comments are provided to teachers.

Therefore, circulars, recent references and clearly defined guidelines should be prepared and sent to schools. To this end WEO, ZEO and regional education bureau should work together and improve the condition by fulfilling the recommended manuals.

3. School supervision has paramount importance in improving the quality of learning. However, the findings have shown that the service has been handicapped in becoming an effective leadership service by among other things, inadequate budget and heavy work load of supervisors. Therefore, to alleviate these:

a. Sufficient budget has to be appropriated specifically to supervision activities

b. The workload of supervisors has to be reduced so that they can get time to handle those supervisory roles effectively. These can be possible by the collaborative work of REB in teacher's assignment and budget allocation processes.

\section{Reference}

Adams, H.P, And Dickey,Frank G.(1986). Basic principles of supervision.

Agarwal, R.D (1993). Organization and Management. New Delhi. Tata Mcgraw hill.

Carron. G.A De Grawue and Govinda (1998). Supervision and support services in Asia: A Comparative Analysis paris:UNESCO.

Dull, Lw (1981) supervision: school Leadership Handbook. Ohio: Charles E

Haileselassie Woldegrima(N.D). (2002) "supervision” AAU, Unpublished Lecture Note.

Harris,Ben M. (1985). Supervisory Behavior in Education. ( $3^{\text {rd }}$ Ed.) New Hersey: pricton -Hall, Inc London: Rout Ledge

Lovell, J.T, (1983)supervision for better schools( $5^{\text {th }}$ Ed.) New Jersey: Englewood,Cliffs,prentice-Hall

Mbamba, Mauno A (1992). Book of Reading in Educational Management. Harare. UNESCO. Merril publishing Co. 
MOE(1994).Education and Training policy. Addis Ababa, Ethiopia

Mohanty, B (1990). School Administration and supervision New Delhi; Deep and publications. New York: Mcgraw- Hill,Inc. NewYork:Application Century crofts.

OEB(2006), Oromia Education Bureau. Addis Ababa, Ethiopia

Otto, H.J., and D.C. Sanders (1962). Elementary school Organization and Administration

Segiovanni, T.J.and Robbert J.starrat (1993).Supervision: A Redefinition.

Singhal, R.et.al (1996).School Inspection system: A modern Approach. New Delhi: Vikas.

Tarrant, T. And Newton (1992). Managing Change in Schools: A practical Handbook.

Ukeje B. (1992). Educational Administration. Enugu: Fourth Dimension publishing co, Ltd. 